\title{
PERAN BAHAN ORGANIK DALAM MENURUNKAN DAMPAK PAPARAN PESTISIDA TERHADAP KESUBURAN TANAH DAN SERAPAN HARA TANAMAN SAWI
}

\author{
The Role of Organic Matter in Reducing the Impact of Pesticide \\ Exposure on Soil Fertility and Green Mustard Nutrient Uptake
}

\author{
Novalia Kusumarini*, Sayifudin, Feppy Nuzula Kautsar, Syekhfani \\ Jurusan Tanah, Fakultas Pertanian Universitas Brawijaya, Jl. Veteran No. 1, Malang 65145 \\ *Penulis korespondensi: novakusuma8@gmail.com
}

\begin{abstract}
Pesticide exposure in the soil is indicated to affect soil fertility as well as nutrient uptake by the plant due to its active ingredient that can affect soil sorption. This research focused on organic matter effect on soil fertility ( $\mathrm{pH}$, organic- $\mathrm{C}, \mathrm{N}, \mathrm{P}, \mathrm{K})$ in the soil under several doses of pesticide exposure as well as nutrients $(\mathrm{N}, \mathrm{P}, \mathrm{K})$ uptake by the green mustard plant. Treatments consisted of control, $\mathrm{d}$ and four doses of pesticide application $(50 \%, 100 \%, 150 \%, 200 \%$ of recommendation dose), four doses of pesticide application combined with two doses of manure application $\left(0\right.$ and $\left.2 \mathrm{t} \mathrm{ha}^{-1}\right)$. Soil $\mathrm{pH}$, organic $\mathrm{C}, \mathrm{N}, \mathrm{P}$, and $\mathrm{K}$ were measured before treatments and after harvest. Nutrients uptake $(\mathrm{N}$, $\mathrm{P}, \mathrm{K})$ and yield of green mustard were measured at harvest. Results of the study showed that the exposure of pesticide in soil reduced the yield of green mustard by $40 \%$ compared to control. Nutrients $(\mathrm{N}, \mathrm{P}, \mathrm{K})$ uptake by plant decreased by $72 \%, 92 \%$, dan $78 \%$ compared to control in soil with exposure of $0,2 \mathrm{ml}$ pesticide $500 \mathrm{ml}^{-1}$ water even though with the addition of organic matter.
\end{abstract}

Keywords: exposure, nutrient uptake, organic matter, pesticide

\section{Pendahuluan}

Penggunaan pestisida lazim digunakan oleh petani dalam setiap kegiatan budidaya, khususnya tanaman hortikultura. Penggunaan pestisida pada tanaman hortikultura seringkali tidak menggunakan dosis yang sudah direkomendasikan. Petani seringkali menggunakan perkiraan dalam menetapkan kebutuhan pestisida, sehingga penggunaan pestisida menjadi overdosis. Hardjowigeno (2003) menyebutkan bahwa hanya $20 \%$ pestisida yang tepat sasaran, $80 \%$ pestisida yang diaplikasikan jatuh mengenai tanah. Hal ini menyebabkan permasalahan bagi tanah. Beberapa penelitian menyebutkan bahwa pestisida menyebabkan kerusakan tanah baik dari fisika, kimia, maupun biologi tanah (Sutanto, 2001; Setiyo et al, 2011). Pestisida menjadi berbahaya bagi tanah karena bahan aktifnya merupakan bahan kimia buatan sehingga asing terhadap sistem tanah (Sutanto, 2001). Bahan aktif pestisida dapat mempengaruhi keseimbangan kompleks jerapan di dalam tanah. Hal ini memungkinkan untuk mempegaruhi keseimbangan hara atau kadar kemasaman tanah.

Keseimbangan hara di dalam tanah dapat mempengaruhi serapan hara oleh tanaman. Jerapan salah satu unsur akan mempengaruhi keseimbangan unsur hara dalam tanah, sehingga mampu mempengaruhi ketersediaan unsur hara yang dapat diserap oleh tanaman (Essays UK, 2013). Kemampuan bahan aktif pestisida dalam mempengaruhi penyerapan unsur hara akan dipelajari melalui penelitian ini.

Bahan organik memiliki peran dalam kompleks jerapan tanah. Bahan organik mampu meningkatkan Kapasitas Tukar Kation (KTK) tanah melalui muatan negative yag disumbangkan pada proses dekomposisi pada 


\section{Jurnal Tanah dan Sumberdaya Lahan Vol 7 No 1 : 127-133, 2020 \\ e-ISSN:2549-9793, doi: 10.21776/ub.jts1.2020.007.1.16}

gugus $\mathrm{OH}$ - dan $\mathrm{COOH}$-. Aplikasi bahan organik diharapkan mampu menurunkan tingkat meracun pada tanah akibat residu pestisida karena bahan organik dapat menjerap senyawa bahan aktif pestisida. Bahan organik memiliki peran dalam menurunkan kandungan pestisida secara nonbiologis, yakni dengan cara mengabsorb pestisida dalam tanah (Gondar et al., 2013). Selain itu, penambahan bahan organik terhadap tanah tercemar pestisida bermanfaat untuk mendukung populasi mikroba yang kemudian efektif memineralisasi residu pestisida menjadi nutrisi tanah (Sulistinah et al., 2011).

Penelitian ini bertujuan untuk untuk mempelajari pengaruh bahan organik dalam menurunkan dampat residu pestisida akibat paparan pestisida terhadap sifat kimia tanah dan serapan N, P, K pada tanaman hortikultura. Tanaman hortikultura yang dipilih sebagai tanaman indicator adalah sawi. Sawi merupakan salah satu tanaman yang dimanfaatkan luas oleh masyarakat karena memiliki nilai gizi yang tinggi seperti energi, protein, lemak, karbohidrat dan lain-lain (Rukmana, 2005). Apabila diketahui bahwa pestisida dapat mengganggu serapa hara hingga pertumbuhan tanaman sawi maka dapat disarankan penggunaan pestisida secara bijak agar kegiatan pertanian hortikutura dapat berkelanjutan.

\section{Metode Penelitian}

Penelitian dilaksanakan di rumah kaca pada bulan September 2018 hingga Januari 2019. Sampel tanah diambil dari Desa Torongrejo, Kecamatan Junrejo, Kota Batu yang merupakan sentra pertanian hortikultura. Bahan organik yang digunakan adalah kotoran sapi yang diambil dari Kecamatan Pujon. Sampel tanah dan bahan organik selanjutnya dikering-anginkan dan diayak dengan ayakan $2 \mathrm{~mm}$. Hasil analisa dasar kandungan hara pada sampel tanah dan bahan organik disajikan dalam Tabel 1.

Sampel tanah dan bahan organik selanjutnya dicampur sesuai dengan perlakuan ke dalam polybag dengan ukuran $5 \mathrm{~kg}$. Dosis bahan organik yang diberikan setara dengan $20 \mathrm{t} \mathrm{ha}^{-1}$. Paparan pestisida dilakukan dengan menyiramkan pestisida berbagai konsentrasi sesuai dengan perlakuan yang dilarutkan dalam $500 \mathrm{ml}$ air. Pestisida yang digunakan adalah Decis 2.5EC. Perlakuan yang diuji coba terdiri atas sembilan perlakuan yang merupakan kombinasi aplikasi pertisida dan pupuk kendang sapi, yaitu P0 (tanpa pestisida), P1 (pestisida dosis 0,2 ml), P2 (pestisida dosis $0,4 \mathrm{ml}$ ), P3 (pestisida dosis 0,6 $\mathrm{ml}$ ), P4 (pestisida dosis $0,8 \mathrm{ml}$ ), P5 (pestisida dosis $0,2 \mathrm{ml}+$ pupuk kandang sapi), P6 (pestisida dosis $0,4 \mathrm{ml}+$ pupuk kandang sapi), P7 (pestisida dosis $0,6 \mathrm{ml}+$ pupuk kandang sapi) dan P8 (pestisida dosis $0,8 \mathrm{ml}+$ pupuk kandang sapi).

Tabel 1. Hasil analisis dasar tanah dan bahan organik (pupuk kendang sapi).

\begin{tabular}{lcc}
\hline Parameter & Tanah & $\begin{array}{c}\text { Pupuk } \\
\text { Kandang }\end{array}$ \\
\hline $\mathrm{pH} \mathrm{H}_{2} \mathrm{O}$ & 5,62 & 6,58 \\
C-organik (\%) & 0,78 & 6,23 \\
N-total (\%) & 0,06 & 0,64 \\
P-tersedia (ppm) & 63,29 & 29,56 \\
K-dd (me 100 g $\left.\mathrm{g}^{-1}\right)$ & 4,66 & \\
K-total $(\mathrm{ppm})$ & & 19,51 \\
\hline
\end{tabular}

Sembilan perlakuan tersebut disusun dalam rancangan acak lengkap dengan tiga ulangan. Tanah yang telah disemprotkan pestisida didiamkan hingga 7 hari kemudian ditanami tanaman sawi yang telah telah berumur 14 hari. Tinggi tanaman sawi diamati setiap minggu sejak tanaman berumur 1 minggu setelah tanam hingga panen. Tinggi tanaman diukur mulai dari permukaan tanah hingga titik tumbuh terakhir. Jumlah daun tanaman sawi diamati setiap minggu. Daun yang dihitung adalah daun yang telah membuka sempurna. Hasil tanaman sawi adalah berat segar tanaman sawi. Parameter saat panen sawit diamati sifat kimia tanah (C-organik, $\mathrm{pH} \mathrm{H}_{2} \mathrm{O}, \mathrm{N}$-total, P-tersedia, dan $\mathrm{K}$-dd), bobot tanaman (segar dan kering), dan serapan N, P dan $\mathrm{K}$ oleh tanaman sawi. Data yang diperoleh selanjutnya di analisis mengunakan Analysis of Variance (ANOVA) pada software Genstat dan dilanjutkan dengan Uji Duncan pada taraf 5\% apabila dalam analisis ragam berpengaruh nyata.

\section{Hasil dan Pembahasan}

\section{Pertumbuhan dan hasil tanaman}

Secara statistik, aplikasi perlakuan berpengaruh nyata $(p<0,05)$ terhadap tinggi tanaman sawi pada umur 14 dan 21 HST. Rerata tanaman tertinggi terdapat pada perlakuan control (tanpa 
pestisida) yaitu 25,5 cm. Diketahui bahwa semakin tinggi dosis pestisida yang dipaparkan ke tanah, tinggi tanaman sawi semakin rendah. Tanaman terendah terdapat pada perlakuan P2 (pestisida dosis $0,4 \mathrm{ml}$ ), yaitu $19,9 \mathrm{~cm}$ atau menurun sebesar $22 \%$ dibandingkan control. Aplikasi bahan organik mampu meningkatkan tinggi tanaman lebih baik dibandingkan tanpa aplikasi bahan organik pada tingkat dosis paparan pestisida yang sama. Namun, tidak dapat melampaui tinggi tanaman sawi pada media tanam yang tidak terpapar pestisida (Gambar 1). Secara statistik, perlakuan mempengaruhi jumlah daun sawi pada umur 21 dan 28 HST $(p<0,05)$. Jumlah daun terbanyak terdapat pada perlakuan control (tanpa pestisida) yaitu 13 helai. Terlihat bahwa aplikasi pestisida mampu menurunkan jumlah daun sawi. Namun, aplikasi bahan organik tidak secara signifikan meningkatkan jumlah daun sawi pada tingkat dosis paparan pestisida yang sama (Gambar 1). Penurunan pertumbuhan tanaman sawi diduga karena penurunan serapan hara hara tanaman yang ditanam pada tanah yang terpapar pestisida (Tabel 2). Zhang et al. (2011) menyatakan bahwa pestisida dapat menurunkan pertumbuhan kubis (Brassiwa chinensi L) akibat bahan aktif yang menjadi inhibitor bagi pertumbuhan akar tanaman.
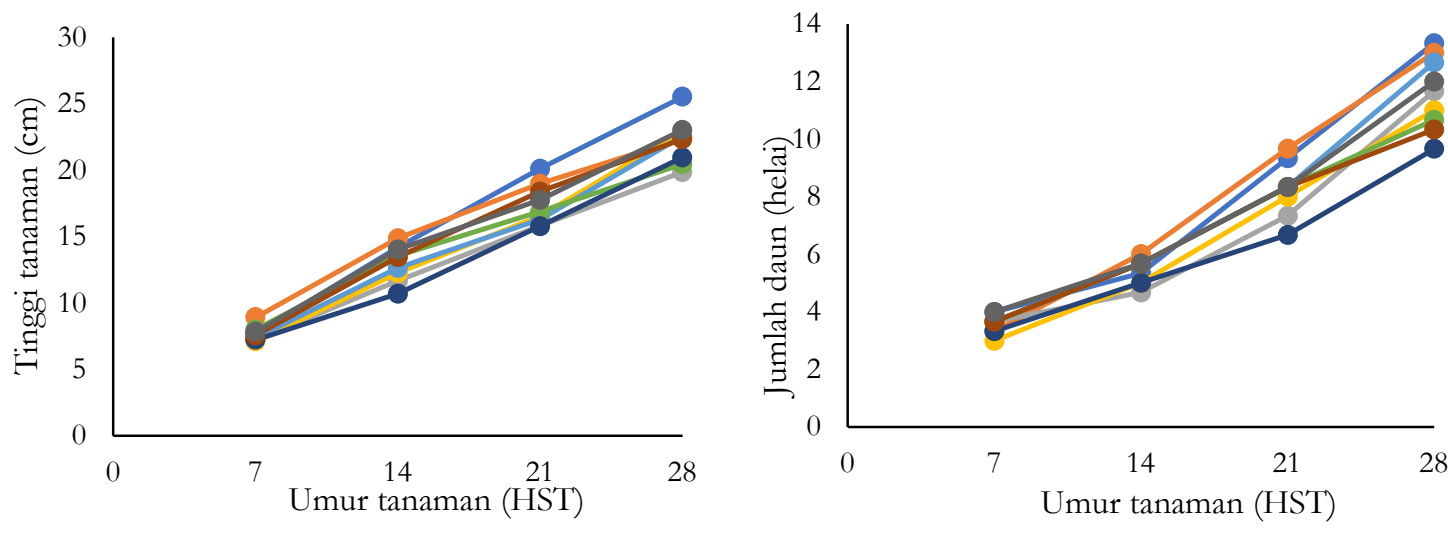

$$
\longrightarrow \text { PO }
$$
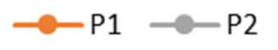

$$
-\mathrm{P3}
$$
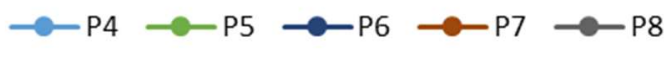

Gambar 1. Pola pertumbuhan tanaman sawi pada berbagai perlakuan dosis paparan pestisida. Keterangan perlakuan: P0 (tanpa pestisida), P1 (pestisida dosis 0,2 ml), P2 (pestisida dosis 0,4 ml), P3 (pestisida dosis $0,6 \mathrm{ml}$ ), P4 (pestisida dosis $0,8 \mathrm{ml}$ ), P5 (pestisida dosis $0,2 \mathrm{ml}+$ pupuk kandang sapi), P6 (pestisida dosis 0,4 $\mathrm{ml}+$ pupuk kandang sapi), P7 (pestisida dosis $0,6 \mathrm{ml}+$ pupuk kandang sapi) dan P8 (pestisida dosis $0,8 \mathrm{ml}+$ pupuk kandang sapi).

Secara statistik, berat segar tanaman sawi dipengaruhi oleh perlakuan. Dosis pestisida berpengaruh terhadap berat segar tanaman sawi. Semakin tinggi dosis pestisida yang terpapar di tanah, maka semakin rendah berat segar tanaman sawi (Gambar 2). Berat segar tertinggi tertinggi terdapat perlakuan P5 (pestisida dosis $0,2 \mathrm{ml}+$ pupuk kandang sapi), yaitu sebesar 85,3 g. Namun, dengan meningkatnya dosis paparan pestisida justru menurunkan berat segar tanaman sawi meskipun telah ditambahkan bahan organik.

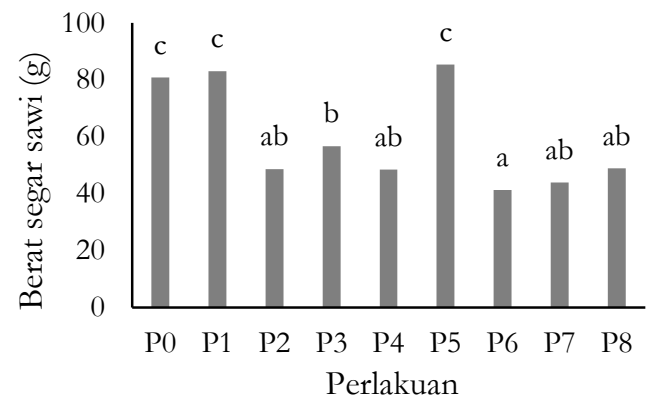

Gambar 2. Berat segar tanaman sawi pada berbagai perlakuan dosis paparan pestisida. Keterangan perlakuan sama dengan Gambar 1. 


\section{Jurnal Tanah dan Sumberdaya Lahan Vol 7 No 1 : 127-133, 2020 \\ e-ISSN:2549-9793, doi: 10.21776/ub.jts1.2020.007.1.16}

Hasil yang sama dikemukakan oleh Glover dan Tetteh (2008) yang menyatakan bahwa paparan insektisida seperti lindane ketika diaplikasikan pada konsentrasi (156 dan $125 \mathrm{~g} / \mathrm{ha})$ menghambat aktivitas mikroba juga hasil panen untuk tanaman sayuran. Hasil tanaman juga menurun bila dibandingkan tanpa pengolahan lahan menggunakan inskektisida lindane.

\section{Serapan hara oleh tanaman sawi}

Serapan hara $(\mathrm{N}, \mathrm{P}, \mathrm{K})$ adalah jumlah hara $\mathrm{N}, \mathrm{P}$, $\mathrm{K}$ yang masuk ke dalam tubuh tanaman sawi. Secara statistik, aplikasi perlakuan berpengaruh nyata $(p<0,05)$ terhadap serapan $N, P$, dan $K$ tanaman sawi. Serapan hara lebih tinggi pada tanah yang tidak terpapar pestisida dibandingkan pada tanah yang terpapar pestisida. Aplikasi bahan organik menghasilkan serapan hara tanaman lebih tinggi dibandingkan tanpa aplikasibahan organik pada level dosis paparan pestisida yang sama. Serapan hara tanaman sawi disajikan dalam Tabel 2. Serapan N tanaman tertinggi terdapat pada perlakuan P3 dan tidak berbeda nyata dengan perlakuan P0 (tanpa pestisida). Paparan pestisida ke dalam tanah memiliki kecenderungan menurunkan serapan $\mathrm{N}$ tanaman. Pola yang sama terjadi pada serapan $\mathrm{P}$ dan K. Serapan $\mathrm{P}$ tertinggi terdapat pada perlakuan P3 dan tidak berbeda nyata dengan P0. Serapan $\mathrm{K}$ tertinggi terdapat pada perlakuan $\mathrm{P} 0$ (tanpa pestisida). Sebaliknya serapan $\mathrm{N}$ dan $\mathrm{P}$ terendah terdapat pada perlakuan P2. Aplikasi bahan organik dapat mempengaruhi serapan hara pada tanah yang terpapar pestisida. Hal ini karena bahan organik meningkatkan koloid jerapan dalam tanah sehingga dapat menjerap bahan aktif pestisida dan mampu melepaskan ikatan dengan hara sehingga hara menjadi tersedia. Diduga serapan hara berkompetisi dengan serapan pestisida oleh tanaman. Pestisida dapat terserap oleh tanaman yang jumlahnya bervariasi tergantung pada iklim, bahan organik tanah dan kadar air, karakteristik tanaman (laju transpirasi, kadar lipid akar), sifat fisiko-kimia dari senyawa dan kehadiran beberapa kontaminan (Collins et al., 2006; Motoki et al., 2015). Konsentrasi pestisida yang tinggi di dalam tanah berpeluang lebih tinggi dibandingkan konsentrasi pestisida yang lebih rendah (Hwang et al., 2017). Pestisida yang terserap sehingga mempengaruhi pertumbuhan tanaman.

Tabel 2. Serapan hara N, P, K pada tanaman sawi.

\begin{tabular}{llccc}
\hline Kode & Perlakuan & Serapan N & $\begin{array}{c}\text { Serapan P } \\
\text { (g tanaman }\end{array}$ & Serapan K \\
& & & $0,012 \mathrm{~d}$ & $0,32 \mathrm{e}$ \\
\hline P0 & Tanpa pestisida & $0,18 \mathrm{~d}$ & $0,003 \mathrm{ab}$ & $0,14 \mathrm{ab}$ \\
P1 & Pestisida dosis 0,2 ml & $0,10 \mathrm{ab}$ & $0,001 \mathrm{a}$ & $0,12 \mathrm{ab}$ \\
P2 & Pestisida dosis 0,4 ml & $0,08 \mathrm{a}$ & $0,013 \mathrm{~d}$ & $0,28 \mathrm{de}$ \\
P3 & Pestisida dosis 0,6 ml & $0,19 \mathrm{~d}$ & $0,007 \mathrm{c}$ & $0,21 \mathrm{c}$ \\
P4 & Pestisida dosis 0,8 ml & $0,13 \mathrm{bc}$ & $0,001 \mathrm{a}$ & $0,07 \mathrm{a}$ \\
P5 & Pestisida dosis 0,2 ml + pupuk kandang sapi & $0,05 \mathrm{a}$ & $0,003 \mathrm{ab}$ & $0,13 \mathrm{ab}$ \\
P6 & Pestisida dosis 0,4 ml + pupuk kandang sapi & $0,09 \mathrm{a}$ & $0,005 \mathrm{bc}$ & $0,17 \mathrm{bc}$ \\
P7 & Pestisida dosis 0,6 ml + pupuk kandang sapi & $0,11 \mathrm{abc}$ & $0,007 \mathrm{c}$ & $0,23 \mathrm{~cd}$ \\
P8 & Pestisida dosis 0,8 ml + pupuk kandang sapi & $0,14 \mathrm{c}$ & & \\
\hline
\end{tabular}

\section{Status kesuburan tanah yang terpapar pestisida}

Untuk menilai kesuburan tanah, parameter yang diukur pada penelitian ini adalah $\mathrm{pH}, \mathrm{C}$-organik, $\mathrm{N}$ total, $\mathrm{P}$ tersedia, dan Kdd. Analisa dilakukan pada saat memaparkan pestisida (0 MSI) dan setelah tanaman sawi panen (4 MST). Secara statistik, perlakukan penelitian secara nyata berpengaruh terhadap pH, C-Organik, $\mathrm{N}$ total, $\mathrm{P}$ tersedia dan Kdd tanah (Gambar 3).

NilaipH tanah

Pada awal aplikasi pestisida (0 MSI), $\mathrm{pH}$ tanah tidak langsung terpengaruh. $\mathrm{Ph}$ tanah berkisar antara 5,59-5,69 dan berada pada kriteria agak masam. Pada 4 MST, ph tanah berbeda nyata antar perlakuan dengan nilai berkisar antara 5,59- 


\section{Jurnal Tanah dan Sumberdaya Lahan Vol 7 No 1 : 127-133, 2020 \\ e-ISSN:2549-9793, doi: 10.21776/ub.jts1.2020.007.1.16}

5,91. Meskipun masih dalam kriteria yang sama, namun ada indikasi peningkatan $\mathrm{pH}$ tanah. Namun, peningkatan ph tanah tersebut diindikasikan akibat aplikasi bahan organik bukan akibat paparan pestisida. Hal ini disebabkan karena $\mathrm{pH}$ tinggi cenderung pada perlakuan aplikasi bahan organik. Sementara $\mathrm{pH}$ tanah pada perlakuan tanpa bahan organik tidak ada kecenderungan peningkatan atau penurunan. Hal tersebut disebabkan karena degradasi abiotik deltametrin stabil pada $\mathrm{pH} 5$ sampai $\mathrm{pH} 7$ suhu $\left(25^{\circ} \mathrm{C}\right)$, menyebabkan nilai $\mathrm{pH} \mathrm{H}_{2} \mathrm{O}$ tanah tidak mengalami aktivitas penurunan ataupun peningkatan yang singnifikan (Standing Committee on Biocidal Products, 2011). Meningkatnya $\mathrm{pH} \quad \mathrm{H}_{2} \mathrm{O}$ juga diduga karena adanya proses dekomposisi bahan organik di dalam tanah. Bahan organik kandang sapi yang diberikan pada media tanam mengalami humifikasi membentuk humus, sehingga terjadi mineralisasi humus mengahasilkan kation-kation basa yang meningkatkan $\mathrm{pH} \quad \mathrm{H}_{2} \mathrm{O}$. Hardjowigeno (2003) menyatakan bahwa pupuk organik yang diberikan ke tanah berkaitan terhadap kesuburan tanah, yang berpengaruh pada beberapa sifat kimia tanah.

\section{Kandungan C-organik tanah}

Kandungan C-Organik tanah pada awal inkubasi pestisida tidak secara signifikan dipengaruhi oleh perlakuan, namun pada akhir percobaan perlakuan berpengaruh nyata terhadap Corganik. Kandungan C-Organik tanah meningkat setelah percobaan penanaman sawi. Secara umum, pestisida tidak mempengaruhi kandungan C-Organik tanah aplikasi bahan organik mampu meningkatkan kandungan COrganik tanah. Takata et al. (2011) menunjukkan bahwa pemberian kotoran sapi dapat meningkatkan kadar C-organik dalam larutan tanah. Aplikasi bahan organik diharapkan mampu menurunka bahan aktif pestisida. Pelepasan deltametrin dapat dipertahankan oleh matriks tanah atau perombakan deltametrin dalam bentuk endapan pada tahap larutan. Fenomena tersebut terjadi pada konsentrasi awal yang tinggi. Hasil itu mengindikasikan bahwa deltametrin dipertahankan oleh fraksi bahan organik tanah. Bahan organik terlarut dapat bertindak sebagai pelarut bersama dalam disolusi dari deltametrin, yang pembentukan endapannya selama 6 jam pertama reaksi. Deltametrin mungkin juga diserap oleh mekanisme lain seperti hidrofilik, hidrofobik, dan elektrostatik (Zhu dan Selim, 2002).

\section{Kandungan $N$ total tanah}

Aplikasi perlakuan tidak berpengaruh terhadap $\mathrm{N}$ total tanah pada awal inkubasi pestisida tetapi berpengaruh nyata terhadap $\mathrm{N}$ total tanah setelah panen. Kandungan $\mathrm{N}$ total tanah pada $0 \mathrm{MSI}$ relatif sama yaitu sebesar $0,07 \%$ dan nilai terendah terdapat pada perlakuan tanpa pestisida (P0) sebesar $0,06 \%$. Sedangkan pada N-total akhir tertinggi terdapat pada perlakuan P5 (pestisida dosis 0,2 $\mathrm{ml}+$ pupuk kandang sapi) dan P6 (pestisida dosis 0,4 ml + pupuk kandang sapi) sebesar $0,08 \%$ dan nilai terendah terdapat pada perlakuan P0 (tanpa pestisida) sebesar $0,06 \%$. Terjadi peningkatan kandungan $\mathrm{N}$ dalam tanah saat panen. Peningkatan tersebut diduga karena adanya penambahan pupuk dasar Urea 1 hari sebelum tanam dan 14 HST. Selain itu, kandungan $\mathrm{N}$ juga mengalami peningkatan nilai yang signifikan pada perlakuan pestisida + pupuk kandang sapi. Hal ini mengindikasikan bahwa telah terjadi pelepasan hara dari proses dekomposisi bahan organik ke dalam tanah sebagai stimulant bertambahnya $\mathrm{N}$ dalam tanah. Dalam penelitian Afandi et al. (2015) menyatakan bahwa pemberian bahan organik dapat meningkatkan kandungan N-total tanah. Meskipun kandungan $\mathrm{N}$ mengalami peningkatan dalam tanah, akan tetapi tidak mampu meningkatkan serapan $\mathrm{N}$ tanaman (Tabel 3).

\section{Kandungan P tersedia tanah}

Secara statistik, kandungan $\mathrm{P}$ tersedia tanah tidak dipengaruhi oleh perlakuan dosis pestisida. Meskipun demikian, ada kecenderungan peningkatan $\mathrm{P}$ tersedia setelah percobaan penanaman. Peningkatan kandungan P-tersedia dalam tanah disebabkan oleh penambahan pupuk dasar SP-36 dan bahan organik. Kandungan $\mathrm{P}$ yang tinggi dalam tanah efektif terhadap serapan hara $\mathrm{P}$ tanaman perlakuan $\mathrm{P} 0$ (tanpa pestisida) sehingga mampu meningkatkan pertumbuhan dan produksi. Sebaliknya pada perlakuan penambahan pestisida, tingginya $\mathrm{P}$ tersedia tidak diikuti peningkatan serapan $\mathrm{P}$ tanaman (Tabel 2). Selain itu, penambahan pupuk $\mathrm{P}$ anorganik tidak memberikan hasil yang optimal terhadap hasil sawi hijau. Hal ini sesuai dengan Glover dan Tetteh (2008) menjelaskan 
bahwa kerusakan pestisida tertentu mengarah pada peningkatan ketersediaan nutrisi tanaman di tanah sehingga mempengaruhi hasil panen.
Sehingga menyebabkan penumpukkan kandungan $\mathrm{P}$ di tanah.
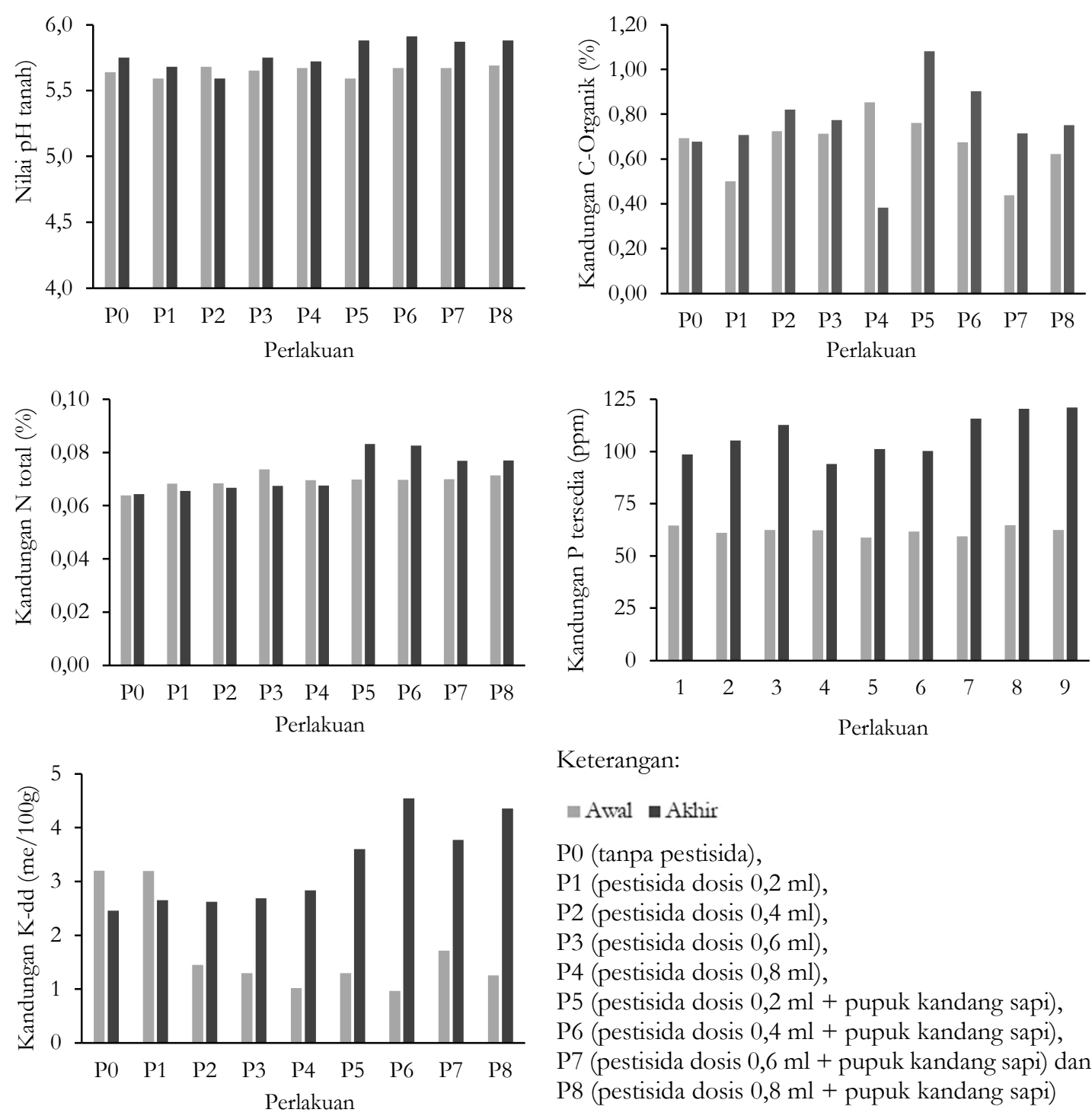

Keterangan:

\section{awal $\square$ Akhir}

P0 (tanpa pestisida),

P1 (pestisida dosis $0,2 \mathrm{ml}$ ),

P2 (pestisida dosis $0,4 \mathrm{ml}$ ),

P3 (pestisida dosis $0,6 \mathrm{ml}$ ),

P4 (pestisida dosis $0,8 \mathrm{ml}$ ),

P5 (pestisida dosis 0,2 $\mathrm{ml}+$ pupuk kandang sapi),

P6 (pestisida dosis $0,4 \mathrm{ml}+$ pupuk kandang sapi),

P7 (pestisida dosis 0,6 $\mathrm{ml}+$ pupuk kandang sapi) dan

P8 (pestisida dosis $0,8 \mathrm{ml}+$ pupuk kandang sapi)

Gambar 3. Kandungan hara tanah yang terpapar pestisida pada berbagai tingkat dosis.

\section{Kandungan K-dd tanah}

Secara statistik, aplikasi perlakuan berpengaruh nyata terhadap K-dd tanah baik pada awal inkubasi pestisida maupun setelah percobaan menanam. Pada awal inkubasi pestisida, terdapat kecenderungan penurunan K-dd tanah akibat aplikasi pestisida. Diketahui bahwa semakin tinggi dosis aplikasi pestisida, maka semakin rendah kandungan K-dd tanah. Pada penelitian Zhu dan Selim (2002) menjelaskan bahwa deltamerin menunjukan retensi yang kuat dari waktu ke waktu untuk semua studi tanah yang diamati. Setelah percobaan penanaman, terjadi kecenderungan peningkatan K-dd tanah. Peningkatan K-dd tanah dapat terjadi akibat penambahan pupuk $\mathrm{KCl}$ selama musim tanam dan penambahan bahan organik. Perlakuan yang 


\section{Jurnal Tanah dan Sumberdaya Lahan Vol 7 No 1 : 127-133, 2020 e-ISSN:2549-9793, doi: 10.21776/ub.jts1.2020.007.1.16}

ditambahkan bahan organik mempunyai K-dd lebih tinggi dibandingkan tanpa bahan organik pada level dosis paparan pestisida yang sama. Hal ini sesuai dengan Sulistinah et al. (2011) menyatakan bahwa penambahan bahan organik terhadap tanah tercemar pestisida bermanfaat untuk mendukung populasi mikroba yang efektif memineralisasi residu pestisida menjadi nutrisi tanah. Oleh sebab itu, kondisi tanah erat sekali hubungannya dengan kadar bahan organik, semakin tinggi kadar bahan organik semakin tinggi pula pestisida yang terjerap (Allison, 1973).

\section{Kesimpulan}

Pertumbuhan dan hasil tanaman sawi menurun pada tanah yang terpapar pestisida. Penurunan hasil sawi terbesar terdapat pada perlakuan P2 (pestisida dosis $0,4 \mathrm{ml}$ ) yaitu sebesar $40 \%$ dibandingkan control (tanpa pestisida). Aplikasi bahan organik mampu meningkatkan pertumbuhan dan produksi lebih tinggi dibandingkan tanpa bahan organik pada tingkat dosis yang sama. Serapan hara N, P, K oleh tanaman menurun akibat paparan pestisida. Serapan N, P, dan K terendah terdapat pada perlakuan P5 (pestisida dosis $0,2 \mathrm{ml}+$ pupuk kandang sapi), yaitu masing-masing menurun sebesar $72 \%$, 92\%, dan $78 \%$ dibandingkan control.Aplikasi bahan organik tidak mampu meningkatkan serapan hara tanaman sawi pada tanah yang terpapar pestisida. Aplikasi pestisida tidak menunjukkan kecenderungan yang sama terhadap peningkatan maupun penurunan kandungan hara tanah. Namun, aplikasi bahan organik mampu meningkatkan kandungan hara tanah setelah percobaan penanaman.

\section{Daftar Pustaka}

Afandi, F.N., Siswanto, B. dan Nuraini, Y. 2015. Pengaruh pemberian berbagai jenis bahan organik terhadap sifat kimia tanah pada pertumbuhan dan produksi tanaman ubi jalar di Entisol Ngrangkah Pawon, Kediri. Jurnal Tanah dan Sumberdaya Lahan 2(2) : 237-244.

Allison, F.E. 1973. Soil Organic Matter and Its Role in Crop Production. Elsevier Scientific Publishing Company, Amsterdam. 1961.

Collins, C., Fryer, M. and Grosso, A. 2006. Plant uptake of non-ionic organic chemicals. Environmental Science and Technology 40: 4552.
Essays, UK. 2013. Nutritional Needs of Plants. Diakses padahttps://www.ukessays.com/essays/biology/factors-affecting-mineralnutrient.php?vref=1, tanggal akses 26 Juni 2018

Glover, A.M. dan Tetteh, F.M. 2008. Effect of pesticide application rate on yield of vegetables and soil microbial communities. West African Journal of Applied Ecology 12: 1.

Gondar, D., Lopez, R., Antelo, J. and Arce, F. 2013. Effect of organic matter and $\mathrm{pH}$ on the adsorption of metalaxyl and penconazole by soils. Journal of Hazardous Materials 260: 627-633

Hardjowigeno, S. 2003. Ilmu Tanah. Akademika Presindo. Jakarta.

Hwang, J.I., Lee, S.E. and Kim, J.E. 2017. Comparison of theoretical and experimental values for plant uptake of pesticides from soil. PLoS ONE 12: e0172254.

Motoki, Y., Iwafune, T., Seike, N., Otani, T. and Akiyama, Y. 2015. Relationship between plant uptake of pesticides and water-extractable residue in Japanese soils. Journal of Pesticide Science 40: 175-183.

Rukmana, R. 2005. Bertanam Sawi dan Petsai. Jakarta: Penebar Swadaya.

Setiyo, Y., Gunam, I.B.W., Gunadnya, I.B.P. and Tika, I.W. 2016. Bioremidiasi In Situ Lahan Tercemar Pestisida oleh Mikroba yang ada pada Kompos. The Exellence Research Univ. Udayana 2011.

Sulistinah, N., Antonius, S. dan Rahmansyah, M. 2011. Pengaruh residu pestisida terhadap pola populasi bakteri dan fungi tanah di rumah kaca. Jurnal Teknologi Lingkungan 12(1): 43-53.

Sutanto, R. 2001. Pencemaran tanah dan air tanah oleh pestisida dan cara menanggulanginya. Jurnal Perlindungan Tanaman Indonesia 7(1) 7ahun 2001.

Takata, Y., Tani, M., Kato, T. and Koike, M. 2011. Effects of land use and long-termorganic matter application on low-molecular-weight organic acids in an Andisol. Journal of Soil Science and Enviromental Management 2(10): 292-298.

Zhang, Z., Shan, W., Song, W., Gong, Y. and Liu, X. 2011. Phytotoxicity and uptake of chlorpyrifos in cabbage. Environmental Chemistry Letters 9 (4): 547-552.

Zhu, H. and Selim, H.M. 2002. Retention and mobility of deltamethrin in soils: 1. Adsorptiondesorption. Soil Science 167(8). 
halaman ini sengaja dikosongkan 